\title{
Research on the Reform of Real Estate Taxation in the Personal Housing Ownership Link
}

\author{
Pan Zhang* \\ Xi'an Polytechnic University, Xi'an 710048, Shaanxi Province, China \\ *Corresponding author: Pan Zhang, amy_kzpp@163.com
}

\begin{abstract}
Housing is related to the well-being of people's livelihood, but at present, the real estate market is overheated, and the price of commercial housing remains high. The implementation of the reform of real estate tax in Shanghai and Chongqing has aroused heated discussions in the society. A timely promotion of real estate tax reform and legislation can play a role in tax regulation. This study takes the reform of real estate tax in regard to personal housing ownership link as the research theme and discusses the setting of collection scheme, the application of tax evaluation technology, as well as tax collection and management.
\end{abstract}

Keywords: Property tax; Personal housing; Ownership link; Tax reform

Publication date: December 2021; Online publication: December 31, 2021

\section{Introduction}

The 14th Five-Year Plan proposed the establishment of a modern fiscal and taxation system as well as to give better play to the basic and important role of finance as a pillar in national governance. As a "tangible hand" to stabilize the real estate market, real estate tax can strengthen the macro-control of the real estate market and optimize the allocation of real estate resources. It is conducive to the establishment of a modern tax system, increase the tax revenue of local governments, and ensure the provision of public goods as well as public services. In recent years, the housing price in most parts of China continues to rise, and the investment scale of the real estate market continues to expand. However, houses are used for living. The reform of personal real estate tax can increase the cost of owning a real estate, inhibit speculative house purchase to a certain extent, and promote the fair distribution of social income.

\section{Real estate tax reform pilot in Shanghai and Chongqing}

\subsection{Shanghai}

In 2011, Shanghai began a pilot collection of personal housing property tax. According to the Interim Measures of Shanghai Municipality for Levying Property Tax on Some Individual Residential Properties, the tax revenue will be used to ensure the expenditure of urban public services, such as the construction of indemnificatory housing. The pilot involves the administrative region of Shanghai, and the collection includes the second and above houses newly purchased by Shanghai resident families in the city (including newly purchased second-hand stock houses and new commercial houses) and those newly purchased by non-Shanghai resident families in the city. The market price of the house is taken as the basis for tax calculation, which is tentatively set at $70 \%$ of the transaction price, and revaluation is carried out regularly according to the specified cycle. The tax rate is temporarily set at $0.6 \%$. If the housing unit price is less than 
two times of the average sales price of new commercial housing from the previous year or less, the tax rate is $0.4 \%$.

Tax relief is applicable as follows: (1) newly purchased resident households in this city belong to the second and above houses, with a family as a unit, the combined area of the newly-purchased house shall not exceed 60 square meters (including 60 square meters) per capita, and the newly-purchased house shall be temporarily exempt from property tax; if the per capita is more than 60 square meters, the excess area of the newly purchased house shall be subjected to property tax; (2) if a resident family has adult children living together, it can be included in the tax-free housing area of the resident family after verification; (3) the property tax paid for the newly-purchased house of the resident family who sells their original only house within one year after purchasing a new house in this city can be refunded; (4) those who meet the relevant regulations of introducing high-level talents and the short supply of talents in key industries, hold city residence permit, as well as work and live in Shanghai can temporarily be exempted from the real estate tax of a newly purchased only house; (5) those who hold a Shanghai residence permit for more than three years as well as live and work in the city will be temporarily exempted from property tax for their newly purchased single-family house; for those who have held residence permit for less than three years, the property tax paid can be refunded after holding the residence permit for more than three years and have worked and lived in the city; (6) For the houses purchased or obtained due to house collection or demolition, the house property tax shall be temporarily exempted; for the area of the house that exceeds the national and municipal compensation standards for house collection and demolition, the area of the house property tax exemption shall be calculated and determined in accordance with the provisions of house property tax. The pilot work in Shanghai took a gradual approach on the basis of the original real estate tax. Shanghai made full use of the transaction taxable price evaluation system used in the deed tax collection and management. With the improvement of the market value assessment system and technology, the real estate tax is gradually transferring to the market value. Shanghai will target investment housing purchase, protect residents' basic housing needs, reasonably adjust residents' income distribution, correctly guide housing consumption, and effectively allocate real estate resources. However, the housing stock involved in the pilot scheme is limited and the tax rate as well as the degree of capitalization are low.

\subsection{Chongqing}

In the Interim Measures of Chongqing Municipality for the Pilot Reform of Levying Property Tax on Some Individual Residential Properties, Chongqing has stipulated that all its tax revenue will be used for the construction and maintenance of public rental houses. The pilot involves nine districts of the main city, and the expropriation objects are temporarily determined as single-family commercial houses owned by individuals, newly purchased high-end residential houses (transaction price $\geq 2 \times$ average transaction price of newly built commercial houses in nine districts of the main city), and the second and above ordinary housing newly purchased by individuals without household registration, enterprise, or job. The taxpayer shall be the owner of the property right of the taxable house, and the taxable value is tentatively determined as the transaction price of the house property, so as to avoid the trouble caused by the evaluation of the house property. The pilot real estate tax rate is divided into three grades according to the transaction unit price. On the basis of the transaction unit price of newly-built commercial residential buildings in the nine districts of the main city in the last two years, for single-family commercial residences and high-end residential buildings, if the average price is less than 3 times, the tax rate is $0.5 \%$; if it is 3 times (including 3 times) to 4 times, the tax rate is $1 \%$; if it is more than 4 times (including 4 times), the tax rate is $1.2 \%$. For individuals who have no household registration, no business, or no job in Chongqing but still purchase a second house or more, including the second set of ordinary housing, the tax rate is $0.5 \%$. 
At the same time, there are also relevant deduction measures for the first set of single-family commercial housing and high-end residential housing in the Interim Measures. Taking a family as a unit, the tax-free area of single-family commercial houses with stock is 180 square meters, and the tax-free area of newly purchased single-family commercial houses and high-end houses is 100 square meters. For multiple sets of newly purchased taxable houses owned by a family, the tax-free area shall be calculated and deducted in chronological order. Therefore, if the building area of the first stock single-family highgrade commercial house purchased by a family is $300 \mathrm{~m}^{2}$, and the unit price of the transaction is 26,000 yuan $/ \mathrm{m}^{2}$, the tax payable $=26000 \times(300-180) \times 1 \%=31,200$ yuan .

At this stage, Chongqing's ten-point property tax is more similar to the luxury tax. It is a penalty tax for luxury houses and high-priced houses. The tax scope is still limited, and the tax rate is low; in that case, the tax scale is also very small. According to the provisions of the Interim Measures, the development direction of Chongqing real estate tax is to include multiple sets of ordinary houses into the collection scope, which is consistent with the tax purpose of "adjusting income distribution and guiding individuals in reasonable housing consumption."

However, it should be noted that, unlike Shanghai, the house prices in Chongqing are relatively stable. It is quite convenient to apply for public rental housing in Chongqing. Almost all low rental housing and public rental housing are open to supply. The rent and the threshold are low. Foreigners working in Chongqing and low-income people can rent. After 5 years, when the lease expires, the tenants can choose to apply for the purchase of the public rental housing. The price is subjected to the comprehensive cost, but they can only live in it. Their children can inherit but cannot be listed for trading. If they want to sell the house, it can only be sold back to the government at the purchase price. The government will pay current interest. The rent paid can be deducted from the house price. Public rental housing, low rental housing, coupled with the huge land supply of commercial housing have kept house prices stable in Chongqing for many years, and real estate speculation has been basically eliminated. In addition, the geographical location of the central and western regions has not experienced the sharp rise of house prices alike in eastern cities, their population inflow is low, and their consumption level lags behind, thus creating a huge gap between the Chongqing model and the Shanghai model.

\subsection{Evaluation and experience of the real estate tax reform pilot in Shanghai and Chongqing}

The overall policies of the two places are consistent; they pay attention to the maintenance of the reasonable housing needs of the residents, give full consideration to the reasonable housing needs of the residents, and set up tax relief policies to further reduce the burden of taxpayers. Both schemes focus on real estate market regulation: Shanghai targeted to crack down on speculation and investment housing purchase, while Chongqing levied taxes on high-priced housings to meet the residents' housing demands and consumption. However, from the results of the pilot, it did not have any effect in restraining the rapid growth of house prices. There are restrictions in the tax scope stipulated in the two schemes. It is basically restricted to new houses purchased by certain individuals; in addition, the tax rate is low, which directly leads to the limited contribution of the real estate tax in Chongqing and Shanghai to the financial revenue as well as the limited role of controlling house prices. Moreover, due to Shanghai's unique super first-tier city status and economic development as well as Chongqing's unique low-rent housing policy, the pilot programs in the two cities have obvious local characteristics and cannot be fully promoted all around the country ${ }^{[1]}$.

\section{Problems in the collection of property tax in the process of personal housing ownership}

\subsection{Problems with the collection scheme}

After learning from the experience of the pilot areas in Shanghai and Chongqing, it has been found that 
there are unreasonable aspects in the non-graded collection scheme, which does not give full play to the role of real estate tax. The scope of the tax system structure is not wide enough. The real estate tax revenue should become the theme tax of the local government to promote an orderly development of the local finance. However, after the introduction of personal real estate tax in 2011, the proportion of Chongqing real estate tax in fiscal revenue increased by only $0.03 \%$, while that of Shanghai decreased by $0.02 \%$. According to data, the impact of real estate tax revenue on fiscal revenue is small.

\subsection{Problems encountered in the application of tax assessment technology}

Due to the dual track system of land supply, the government has two ways of land supply: free allocation and paid transfer. Free allocation and agreement transfer are non-market supply methods. There is no market price for free allocation because it has not been traded. Although the agreement transfer has transaction behavior, it cannot accurately measure the market price. Therefore, it is unreasonable to assume the land price under the above two modes of supply directly as the tax basis at zero or the agreed price. Moreover, for the evaluation of this part of land, an individual cannot simply use the market transaction data to increase the evaluation cost.

The ownership of real estate is chaotic. China's economic system reform and housing reform have led to the diversity of the current housing property right structure. At present, the residential property rights of urban residents can be divided into seven categories: commercial housing property rights, affordable housing property rights, housing property rights built by units using their own land or before 1992, housing reform property rights, private housing property rights, second-hand housing property rights purchased by residents, and all public housing property rights of organs, units, and the Housing Authority. Housing property rights are different, but with the same market evaluation method, it is difficult to ensure tax fairness. At present, China is implementing the leasehold system; that is, the government collects the land use right transfer fee for a certain number of years in a lump sum. The difficulty in calculating the value of a land at a certain time, comparing the value of a land in different years, the conflict between land transfer fee and property tax, as well as double taxation all affect the application of tax assessment technology.

\subsection{Problems with tax collection and management}

There are high requirements for tax collection and management. The tax authorities need to verify and evaluate the situation of each household. The workload is huge; therefore, it is a challenge to the tax collection and management authorities ${ }^{[2]}$. Establishing a dispute settlement mechanism can better solve the problems and objections of taxpayers in the evaluation of taxable prices. However, it is difficult to reasonably set up the disposal process; in addition, the adjustment of disputes requires the establishment of a special dispute team, the investment of human and material resources, as well as a lot of time, in order to conduct field investigations and prepare specific reports. In this process, there may be a risk of information opacity in the selection of professional institutions, and the quality of collection and management personnel may also affect the efficiency of collection and management.

\section{Policy suggestions for the reform of real estate taxation in the personal housing ownership link}

\subsection{Establishing a scientific and reasonable collection scheme}

In the setting of the collection scheme, it is not only necessary to consider the exemption of needed houses, but also to delimit a more reasonable individual exemption area according to the regional economic development and set a progressive tax rate more in line with the regional development. Moreover, because China and foreign countries have different realities, land ownerships, political and economic systems, as well as unbalanced economic development, a tax system that is more in line with national conditions and 
reality should be established.

\subsection{Promoting scientific assessment systems}

The evaluation of stock houses is not only an important tax collection and management work, but also the core link of real estate tax collection. Real estate management departments should rely on the internet to actively establish real estate inventories and register the physical information and rights of all real estate within their jurisdiction, so as to determine the tax base as well as the taxpayers' obligations and rights. The physical information should include the address of the location, the building area, the completion date of the real estate, the building structure, the floor and orientation of the real estate, the nature of the land, and the purpose of the house, while the rights include the nature of ownership, share of property rights, acquisition time, the name of the obligee, certificate number, contact information, etc. ${ }^{[3]}$. Local governments must strengthen the supervision of relevant departments, ensure the smooth progress of all works, as well as actively organize and coordinate the relevant departments to perform well in the evaluation of real estate taxation.

\subsection{Establishing a new real estate tax collection mechanism}

In order to establish an effective tax source information exchange platform, the data interconnection and sharing among the Taxation Bureau, the Housing Administration Bureau, real estate registration management, and civil affairs departments are required. The interfaces involved mainly include the query and tax payment interfaces for house transactions, house sets, etc. with the housing management and real estate registration departments; second, the evaluation interface of the price calling evaluation system; third, the data interface with golden tax phase III; fourth, the marriage inquiry interface with the Civil Affairs Bureau aiming to improve the tax base registration as much as possible and avoiding tax evasion on the premise of a scientific evaluation system. By linking up with banks, establishing a credit investigation system covering the whole network, and effectively monitoring individual real estate tax payment activities when leasing activities between individuals may help to achieve the purpose of paying taxes according to the law for all tax related behaviors as well as adjusting the fairness of income distribution.

\subsection{Strengthening taxpayers' tax awareness}

There is a need to encourage taxpayers to pay taxes according to law and improve their tax awareness. Tax authorities need to strive to guide taxpayers to pay taxes in good faith and give full play to the role of tax publicity. It is necessary to strengthen tax collection and management as well as constantly improve the ideological and professional quality of tax personnel. It is also necessary to resolutely crack down on tax evasion as well as increase penalties and the cost of tax evasion. Other than that, it is important to establish an expert inquiry system, alleviate information asymmetry, strengthen interdepartmental cooperation, and comprehensively promote the construction of an information sharing system between tax departments and other departments. The government needs to improve the transparency of government expenditure, strengthen expenditure management, improve the efficiency, and help taxpayers to clearly understand the role of taxation at the level of social welfare, so as to win the confidence of taxpayers.

\section{Disclosure statement}

The author declares that there is no conflict of interest. 


\section{References}

[1] He Y, 2017, China's Real Estate Tax Reform, China Taxation Press, Beijing, 282.

[2] Li Z, 2014, Research on My Country's Real Estate Tax System Reform. The Party School of the Central Committee of the Communist Party of China.

[3] Yang W, 2015, My Country's Real Estate Tax: Tax System Reform Analysis and Batch Tax Assessment Empirical. Graduate School of Chinese Academy of Social Sciences. 